\title{
Lisbeth Elvebakk
}

Institutt for grunnskole- og faglcererutdanning

Høgskolen i Oslo og Akershus

E-post: lisbeth.elvebakk@hioa.no

Evy Jøsok

Institutt for grunnskole- og faglererutdanning

Høgskolen i Oslo og Akershus

\section{"Et bra prosjekt som har gjort meg til en bedre skriver" - arbeid med skrivestrategier i videregående skole}

\section{Sammendrag}

Temaet for denne artikkelen er skriveopplering i videregående skole. Artikkelen studerer en intervensjon med eksplisitt skriveopplering og innføring av skriveramme. Intensjonen har væert å se hvordan læerere kan samarbeide om skriveoppleringen på tvers av fag, og hvordan femavsnittsmetoden fungerer som redskap og strategi i opplcringen. Vi har primært vært interesserte i elevenes tanker om skriveopplaring og egen skrivekompetanse, og dette ser vi i sammenheng med hvordan faglcererne opplever å samarbeide på tvers av fagene. Datamaterialet vårt er observasjoner og spørreundersøkelser i etterkant av intervensjonen. Analysen viser i hovedsak at elevene opplever at de har hatt nytte av femavsnittsmetoden, og at de ser stor verdi i at lcererne i ulike fag bruker en noenlunde lik tilncerming til skrivingen. Det kommer også fram at elevene finner det utfordrende å skrive gode fagtekster. Svarene fra larerne peker i samme retning. Lcererne oppfatter at felles satsing på skriving er nyttig, og de framhever verdien av lcerersamarbeidet på tvers av fagene. Et interessant funn er at arbeidet med skriverammer har satt i gang betydningsfulle samtaler rundt skriving og tekstkompetanse både i kollegiet og i klasserommene.

Nøkkelord: skolebasert arbeid med skriving, eksplisitt skriveopplaring, skriverammer, femavsnittsmetoden

\begin{abstract}
The subject of this article is discursive writing. The article studies an intervention focusing on explicit teaching and implementation of writing frames in upper secondary school. The aim is to investigate the students' perspectives regarding the teaching and their evaluation of writing competencies. These results are analysed in connection with the teachers' experiences from teacher learning groups across disciplines. Our data are based on observations and surveys from both students and teachers. The results show that in general, the
\end{abstract}


students have benefited from explicit teaching and a common approach across the disciplines. However, they also report on the difficulties regarding discursive writing. The results for the teachers are similar. In addition, they report that teachers' learning communities are valuable. The most interesting finding of this study was that the explicit teaching initiated meaningful discussion concerning learning and student writing.

Keywords: teacher learning communities, explicit teaching, writing frames, five paragraph essays

\section{Innledning}

Innføringen av Kunnskapsløftet har forsterket betydningen av skriving i fagene blant annet gjennom de grunnleggende ferdighetene. Ifølge Kjell Lars Berge (2005, s. 163) innebærer Kunnskapsløftet at faglig kunnskap og språk er knyttet sterkere sammen enn tidligere. Å beherske et fag er ensbetydende med “å utøve fagrelevant skriving, lesing og muntlighet” (Berge, 2005, s. 163). God skrivekompetanse blir dermed viktig for at elevene skal kunne utvikle fagkunnskaper. Et slikt syn på sammenhengen mellom fagkunnskap og språk krever at opplæringen i de språklige ferdighetene får en sentral plass i alle fag, ikke bare i språkfagene. Det krever at faglærerne ikke bare har ansvar for å formidle et faglig innhold, men også de fagspesifikke uttrykksmåtene og fagets tekstkategorier.

Evalueringer av Kunnskapsløftet viser imidlertid at vektleggingen av språklige ferdigheter ikke automatisk har ført til vesentlige endringer i skriveopplæringen i skolen (Hertzberg, 2009, s. 145, 2012, s. 38). Spesielt i videregående skole er skriving først og fremst en måte å evaluere kunnskap på, og opplæring i skriving har en relativt beskjeden plass i fagene. Et sentralt spørsmål er hva som skal til for å få til bedre skriveopplæring. Hvordan kan skriveopplæringen integreres i hvert enkelt fag? Hvordan kan skolen legge til rette for bedre skriveopplæring i fagene? Og hva slags utbytte kan et samarbeid på tvers av fag ha for opplæring i en fagovergripende ferdighet? Denne artikkelen presenterer en studie av en intervensjon gjennomført ved en videregående skole der målet har vært å forbedre elevenes skriveferdigheter gjennom bruk av en felles skriveramme i alle fag, og der samarbeid mellom ulike faglærere har vært sentralt. Arbeidet hadde altså et dobbelt formål: både forbedre elevenes skriveferdigheter og samtidig skape en felles didaktisk plattform for skriveopplæring ved skolen. Studien omfatter observasjoner og spørreundersøkelser gjennomført av 125 elever og 15 lærere på vg1 studiespesialisering i fellesfagene engelsk, geografi, norsk, samfunnsfag og naturfag. Forfatterne, som begge er eller har vært ansatt på skolen, har vært observatører under både planleggingen, gjennomføringen og evalueringen av intervensjonen. 
Vårt forskningsspørsmål er: Hvordan opplever lcererne og elevene innføringen av skriveramme og samarbeid på tvers av fag?

I denne studien har vi vært opptatt av hvilke tanker elevene gjør seg om egen skrivekompetanse og den betydningen eksplisitt skriveopplæring knyttet til fag har hatt for elevenes skriveopplæring. Vi har også vært opptatt av hvilken verdi et faglig samarbeid om en fagovergripende kompetanse har for lærerne.

\section{Hvordan bruke skriveramme i skriveopplæringen?}

Spørsmålet om hvordan man skal legge til rette for god skriveopplæring henger sammen med hvilke utfordringer elevene står overfor. I denne satsingen var fokuset fagtekster der elevene skal gjøre rede for og drøfte fagstoff. Utfordringene i slike tekster ligger delvis i selve innholdet - det å kunne bygge opp faglig argumentasjon eller resonnement - og delvis i den strukturen en slik tekst krever. En del studier av elevtekster de senere årene (bl.a. Øgreid, 2016, 2008; Ligaard, 2012; Igland, 2007; Berge mfl., 2005) peker nettopp på at mange elever har utfordringer knyttet til bearbeiding og organisering av fagstoff, strukturering av fagtekster på både heltekst- og deltekstnivå samt bruk av adekvat fagspråk. De samme utfordringene har elevene ved den skolen der denne satsingen er gjennomført. Lærerne var spesielt opptatt av at elevene strevde med å bygge opp tekster som tilfredsstiller kravene til fagtekster på dette nivået.

For å møte nettopp disse utfordringene trenger elevene konkret og spesifikk støtte knyttet til blant annet strukturering av kunnskapsinnholdet i egen tekstproduksjon hevder Steve Graham og Dolores Perin (2007). De poengterer at undervisning i ulike skrivestrategier er blant de mest effektfulle tiltakene for å utvikle elevenes skrivekompetanse. Det samme påpeker Anne Kristine Øgreid (2016, s. 3). Flere andre norske studier støtter også en slik tilnærming med vekt på eksplisitt undervisning, systematisk bruk av skrivestrategier og faste tekstmønstre i arbeidet med å planlegge, revidere og sluttføre tekster (Øgreid, 2016; Helstad \& Hertzberg, 2013; Håland, 2013; Kringstad \& Kvithyld, 2013; Smidt, 2011). Her er eksplisitt undervisning forstått som all den aktive støtte læreren gir elevene underveis i skriveprosessen (Øgreid, 2016). Denne tenkningen bygger på Vygotskys teori om å bygge stillas for eleven i læringsprosessen. Slike stillas kan være både strategier for arbeidet, konkrete verktøy og metoder, direkte instruksjoner og annen støtte fra læreren.

I den intervensjonen vi har studert, valgte lærerne å bruke femavsnittsmetoden slik den er utformet av Flyum (i Flyum \& Hertzberg, 2011) som en felles tilnærming til skriveprosessen. Metoden har blitt prøvd ut i skriveopplæringen både på ungdomsskoler, i videregående skoler og i høyere utdanning (Øgreid, 2016; Flyum \& Hertzberg, 2011; Ligaard, 2012, 2014). Femavsnittsmetoden er en strategi for tekstproduksjon, men samtidig gir den elevene strukturhjelp i form av en konkret skriveramme (Ligaard, 2012, 2014, s. 23). Som 
strategi for tekstproduksjon gir den elevene en prosedyrehjelp fra planlegging av tekst til ferdig utkast - det Flyum kaller en femavsnittsskisse. Som skriveramme gir metoden først og fremst støtte til å organisere fagstoffet på tekstnivå og til å bygge ut poeng på avsnittsnivå. Skriverammer er tekstlige mønstre og modeller som gir elevene spesifikk hjelp i arbeidet med tekststruktur på både heltekst- og deltekstnivå (Øgreid, 2016; Lewis \& Wray, 2002). Skriverammer kan dermed være modelltekster som gir elevene mønstre for den ferdige teksten, strategier som hjelper elevene til å organisere informasjon, og det kan være startsetninger og tekstbindere tilpasset den konkrete skriveoppgaven.

\section{Forskningsdesign}

Skolens arbeid med skriveopplæring kan defineres som et skolebasert utviklingsarbeid, der målet var forbedring av lærernes praksis rundt skriveopplæring. Arbeidet ble ledet av en prosjektgruppe som besto av avdelingsleder, fire lærere med ulike fagområder og en bibliotekar. Gruppa hadde dermed en tydelig forankring både i ledelsen og i lærerkollegiet. I tillegg til å ha ansvaret for gjennomføringen av intervensjonen ved skolen, representerte prosjektgruppa skolen i et nettverkssamarbeid i skriving mellom Kunnskap i skolen, Institutt for lærerutdanning og skoleforskning ved Universitetet i Oslo samt flere ungdomsskoler og videregående skoler i regionen.

Begge artikkelforfatterne var under hele gjennomføringen ansatt ved skolen som faglærere. Vi var aktive deltakere i prosjektgruppa i tillegg til de andre lærerne, var til stede på alle samlinger i lærerkollegiet og var observatører i felles undervisningsøkter for elevene. Vi har imidlertid ikke hatt undervisning i noen av klassene som var gjenstand for forskningen. Som aktive medlemmer i prosjektgruppa hadde vi anledning til å komme med innspill til innhold og organisering av skriveopplæringen. Vi har dermed hatt muligheter til å være tett på praksisfeltet. En slik tilnærming har både styrker og svakheter. Det kan være problematisk å ha et forskerblikk på en praksis man er delvis deltakende i, men samtidig gir det oss muligheter til å komme tett på læringsprosessene i kollegiet.

Planleggingen, gjennomføringen og evalueringen av intervensjonen ble organisert etter aksjonslæringssirkelen (Postholm \& Jacobsen, 2011), en modell som er basert på at det stilles spørsmål ved en praksis, samles informasjon som kan belyse praksisen, og at denne informasjonen deretter brukes til å sette i gang et tiltak eller en intervensjon. Prosjektgruppa var pådriver i arbeidet med iverksetting, utprøving og refleksjon rundt tiltaket. Sentralt i arbeidet var lærersamarbeid. Målet var å dele erfaringer og kompetanse om skriveopplæring og arbeid med elevtekster på lærernivå for å bedre kunne ivareta elevenes skriveutvikling i tråd med læreplanens krav. 


\section{Praktisk gjennomføring og datainnsamling}

\section{Lærersamarbeid}

Samarbeidet mellom lærerne på trinnet ble organisert gjennom fem felles samlinger ledet av avdelingsleder. Det var ikke satt av ekstra tid til samarbeidet ut over de faste rammene for lærersamarbeid, slik at arbeidet i så stor grad som mulig skulle inngå som del av lærernes ordinære arbeid.

På den første samlingen var temaet femavsnittsmetoden. En norsklærer ved skolen presenterte metoden slik at alle lærere skulle ha en felles forståelse av hvordan femavsnittsmetoden kunne brukes som prosedyrehjelp og skriveramme i skriveopplæringen. Det ble også diskutert hvordan den kunne tilpasses de ulike fagenes tekstkultur. Etter samlingen ble det laget et utkast til en felles skriveramme (se tabell 1) som ble brukt $i$ alle fag.

Tabell 1: Skjematisk framstilling av skriverammen

\begin{tabular}{|l|l|}
\hline Innledning & 1. avsnitt: \\
& Vekke leserens interesse / aktualisere / presentere tema og problemstilling. \\
\hline Hoveddel & 2., 3. og 4. avsnitt: \\
& Alle avsnitt skal bestå av: \\
& En temasetning: en påstand eller et synspunkt. \\
& Kommentarsetninger: forklaringer, argumenter og eksempler som underbygger \\
& temasetningen. \\
& En konkluderende setning: knytter poenget til teksten som helhet. \\
\hline Avslutning & 5. avsnitt: \\
& Oppsummering av de viktigste punktene. \\
\hline
\end{tabular}

Lærersamling to ble viet arbeid med kjennetegn ved de ulike fagenes fagspråk og tekstkulturer, herunder også logiske markører eller tekstbindere i tekstene. En av skolens norsklærere innledet om emnet og lærerne gikk sammen i faggrupper for å jobbe med spesifikke kjennetegn på fagspråk i sitt fag. Arbeidet tok utgangspunkt i elevtekster og munnet ut i fagspesifikke oversikter over viktige begreper.

I samling tre og fire arbeidet lærerne med oppbygging av argumentasjon og resonnement. En samfunnsfaglærer og en naturfaglærer ved skolen startet samlingen med korte innlegg om hva som kjennetegner god argumentasjon i de respektive fagene, før lærerne gikk sammen i tverrfaglige grupper. Det ble lagt vekt på hvordan man i opplæringen kan utnytte likheter, men også synliggjøre fagforskjeller. Den siste samlingen ble satt av til evaluering av arbeidet.

\section{Intervensjonen}

Intervensjonen ble gjennomført i 4 av 5 klasser på vg1 ST og pågikk gjennom et helt skoleår. For elevene ble den praktiske gjennomføringen delt i 3 faser: 1) arbeid med organisering av fagstoff og tekststruktur gjennom bruk av femavsnittsmetoden, 2) arbeid med tekstbinding og fagspråk og 3) arbeid med å bygge opp argumentasjon i fagene. De tre fokusområdene for opplæringen ble 
valgt på bakgrunn av det lærerne erfaringsmessig opplevde som utfordrende for elevene. Tabell 2 viser en oversikt over arbeidet.

Figur 2: Prosjektplan

\begin{tabular}{|l|l|l|}
\hline & Eksplisitt undervisning & Tekstskriving \\
\hline $\begin{array}{l}\text { Fase 1 } \\
\text { august-oktober }\end{array}$ & $\begin{array}{l}\text { Femavsnittsmetoden. } \\
\text { Tekststruktur og organisering av } \\
\text { fagstoff. }\end{array}$ & $\begin{array}{l}\text { Skriving av tekster med bruk av femav- } \\
\text { snittsmetoden i fagene norsk, engelsk, } \\
\text { samfunnsfag, geografi og naturfag. }\end{array}$ \\
\hline $\begin{array}{l}\text { Fase 2 } \\
\text { oktober-januar }\end{array}$ & Fagspråk og tekstbindingsord. & $\begin{array}{l}\text { Skriving av tekster med fokus på tydelig } \\
\text { fagspråk og tekstbinding. }\end{array}$ \\
\hline $\begin{array}{l}\text { Fase 3 } \\
\text { januar-juni }\end{array}$ & $\begin{array}{l}\text { Oppbygging av argumentasjon. } \\
\text { Bruk av kilder. }\end{array}$ & $\begin{array}{l}\text { Skriving av tekster med fokus på opp- } \\
\text { bygging av argumentasjons og drøfting. }\end{array}$ \\
\hline
\end{tabular}

Den første uken i skoleåret ble alle elevene på trinnet samlet til en felles undervisningsøkt ledet av en norsklærer, der femavsnittsmetoden ble gjennomgått. Elevene skrev en femavsnittsskisse som de bygde ut på både tekst- og avsnittsnivå. I de påfølgende ukene ble denne rammen brukt som verktøy i tekstproduksjon i alle de involverte fagene på klassenivå.

Neste fase i skriveopplæringen var å rette oppmerksomheten mot bruk av relevant fagspråk og tekstbindere som markører for å tydeliggjøre struktur og argumentasjon i tekstene. Lærerne tok utgangspunkt i de listene de hadde utarbeidet i fellesskap, og jobbet individuelt i egne klasser. Elevene jobbet med å identifisere språklige uttrykk for argumentasjon og resonnement i eksempeltekster, og de trente på å bruke dem i egne tekster.

I den siste fasen ble det brukt tid på argumentasjon og drøfting. I denne delen av arbeidet ble det også lagt vekt på kildebruk og bearbeiding av fagstoff. Elevene arbeidet med innhenting av informasjon fra ulike kilder, bearbeiding og muntlig trening i argumentasjon. Faglærerne var ansvarlige for gjennomføringen slik at de fagspesifikke forskjellene ble tydeliggjort.

\section{Datainnsamling}

Datamaterialet vi presenterer i denne artikkelen er basert på både kvantitative og kvalitative metoder. I den kvantitative undersøkelsen ble samtlige elever som deltok i satsingen bedt om å fylle ut et standardisert spørreskjema der de vurderte egen skrivekompetanse, altså en form for vurderingsspørsmål (Ringdal, 2014). Slike uttrykk for holdninger er bare delvis målbare, men kan likevel gi interessant informasjon om det spørsmålet som stilles. Av de 125 elevene som var med på skriveprosjektet har 80 \% svart. Dette er en relativt høy svarprosent, som gir oss god mulighet til å kunne si noe spesifikt om den aktuelle elevgruppen.

Elevene ble i spørreskjemaet bedt om å vurdere egen skrivekompetanse etter i hvilken grad de behersker femavsnittsmetoden, argumentasjon og fagspråk i hvert enkelt fag. Dette var de områdene lærerne på forhånd hadde definert som de største utfordringene for elevene. Elevene markerte på en intensitetsskala fra 1 til 10 i spørreskjemaet som måler hvor dypt vurderingen eller oppfatningen 
stikker (Haraldsen, 1999, s. 181). For å forenkle datamaterialet har vi i den videre analysen valgt å gruppere vurderingene i tre, der 1,2,3 representerer "i liten grad", 4,5,6,7 representerer "i middels grad" og 8,9,10 representerer "i stor grad”. Resultatene er framstilt i prosent rundet av til nærmeste heltall. I spørreskjemaet ble de samme spørsmålene stilt for hvert av de fem fagene. Spørsmålene er stilt på en slik måte at det er elevens egen opplevelse av skrivekompetanse som forsøkes målt. Undersøkelsen ble gjennomført på skolens læringsplattform, og vi har hatt tilgang til resultatene klassevis, ikke individuelt for hver enkelt elev. Slik vi har brukt undersøkelsen, har det vært tilstrekkelig, men med individuelle svar hadde vi hatt mulighet for oppfølging av de svarene som ble gitt.

Spørreskjemaet for elevene inneholdt helt til slutt et fritekstfelt der de ble oppfordret til å kommentere egen erfaring med skriving og skolens satsing på skriving. Fritekstfeltet var ikke knyttet til et spesifikt fag. Hensikten var å få fram elevenes synspunkter generelt. Et fritekstfelt gir elevene mulighet til å uttrykke erfaringer som ikke er etterspurt i spørreskjemaet. Slike åpne spørsmål kan gi et skjevt bilde av virkeligheten siden mange kan finne det vanskelig å svare (Haraldsen, 1999, s. 111), men et flertall av elevene benyttet seg av denne muligheten og det har vært nyttige data. Vi ønsket å lese svarene fra elevene så uavhengig som mulig for å se hva de kunne fortelle oss, og vi sorterte derfor materialet i kategorier underveis i lesingen. Vi leste i flere omganger for å finne tematiske kategorier som gjorde at vi fikk fram mange ulike elevstemmer, men samtidig kunne se det typiske. Vi kategoriserte først elevsvarene etter om de var positive til satsingen eller negative, og deretter sorterte vi dem etter hvilke begrunnelser de ga for synspunktene sine.

I spørreundersøkelsen til lærerne ble det brukt et skjema med tre åpne spørsmål. Lærerne ble bedt om redegjøre for hvilket fokus de hadde hatt i skriveopplæringen i sitt fag, hvordan de vurderte elevenes skriveutvikling og hvilke erfaringer de hadde med lærersamarbeidet. Det var 15 lærere med i satsingen, og samtlige har besvart skjemaet. I tillegg til spørreundersøkelsen har lærerne skrevet en evaluering av satsingen, og vi som forskere har observasjonsnotater fra alle fellessamlingene.

\section{Funn}

\section{Hva sier elevene?}

En spørreundersøkelse der elevene egenrapporterer, har begrenset gyldighet og vil på ingen måte uttrykke forholdet mellom skriveopplæring og skrivekompetanse. Elevenes svar gir likevel noen interessante perspektiver på hvordan elevene opplever skriveopplæringen og hva slags betydning de mener læringen har for deres skrivekompetanse. Resultatene er framstilt i tabellen nedenfor. 
Tabell 3: Resultater fra elevundersøkelsen

\begin{tabular}{|l|l|l|l|l|}
\hline Fag & $\begin{array}{l}\text { Behersker fem- } \\
\text { avsnittsmetoden } \\
\text { (struktur på tekst- } \\
\text { og avsnittsnivå) }\end{array}$ & $\begin{array}{l}\text { Behersker argumentasjon } \\
\text { i faget (kunne begrunne } \\
\text { synspunkt og påstander) }\end{array}$ & $\begin{array}{l}\text { Behersker fagspråket } \\
\text { (spesifikke fagord og } \\
\text { logiske markører) }\end{array}$ \\
\hline \multirow{2}{*}{ Engelsk } & I liten grad & 1 & 6 & 10 \\
\cline { 2 - 5 } & Middels & 44 & 68 & 48 \\
\cline { 2 - 5 } & I stor grad & 54 & 26 & 41 \\
\hline Samf.fag & I liten grad & 1 & 1 & 2 \\
\hline & Middels & 35 & 48 & 37 \\
\hline & I stor grad & 64 & 51 & 61 \\
\hline Naturfag & I liten grad & 12 & 9 & 18 \\
\hline & Middels & 65 & 68 & 61 \\
\hline & I stor grad & 23 & 22 & 21 \\
\hline Geografi & I liten grad & 2 & 6 & 6 \\
\hline & Middels & 60 & 61 & 55 \\
\hline & I stor grad & 38 & 33 & 5 \\
\hline Norsk & I liten grad & 1 & 1 & 53 \\
\hline & Middels & 41 & 50 & 42 \\
\hline & I stor grad & 58 & 49 & \\
\hline
\end{tabular}

I den grad vi kan si at det å kunne bygge opp en tekst, argumentere og beherske fagspråk er gyldige som operasjonaliseringer av skrivekompetanse, mener de fleste elevene at de behersker skriving godt. I engelsk, samfunnsfag og norsk svarer mer enn halvparten av elevene at de behersker femavsnittsmetoden i stor grad. De behersker altså et redskap som hjelper dem til å organisere fagstoffet både på tekstnivå og på avsnittsnivå. De behersker også en metode for å komme i gang med tekstskriving.

Elevene uttrykker også at de i middels eller stor grad behersker argumentasjon i faget. Her utmerker samfunnsfag seg spesielt siden over halvparten av elevene mener at de i stor grad behersker argumentasjon. I naturfag, geografi og engelsk derimot mener over halvparten av elevene at de i middels grad behersker argumentasjon. Denne forskjellen er interessant, og en forklaring kan ligge i fagenes egenart og hva elevene oppfatter at det blir brukt tid på i de ulike fagene. Hva elevene legger i begrepet argumentasjon spiller selvsagt også inn.

Når det gjelder bruk av fagspråk, er tallene jevnere. Det er likevel en liten, men interessant forskjell mellom naturfag, geografi, engelsk og norsk på den ene siden og samfunnsfag på den andre. Flertallet av elevene mener de i stor grad behersker fagspråk i samfunnsfag, mens flertallet i middels grad behersker fagspråk i de tre andre fagene. Materialet gir ingen forklaring på denne forskjellen, men det kan være et poeng å se nærmere på en slik forskjell i det videre arbeidet ved skolen.

\section{Fritekstfeltet}

Svarene i fritekstfeltene deler seg i hovedsak i to: positive til skolens satsing på skriveopplæring og negative til satsingen. Et stort flertall uttrykker at de er positive, og begrunnelsene de gir kan sorteres i 4 ulike kategorier: rammen gir 
strukturhjelp på tekstnivå; rammen gir strukturhjelp på avsnittsnivå; kunnskapsoverføring mellom ulike fag; generelle kommentarer.

Flere av elevene poengterer at det å organisere fagstoff og skape god tekststruktur i egne tekster har vært en stor utfordring, og de mener at det å ha en fast form å ta utgangspunkt i, har gjort det lettere å bygge opp en tekst. En elev skriver for eksempel: "Det er svært nyttig og lærerikt å skrive med 5avsnittsmetoden. Jeg bruker det i alle tekster, samt innleveringer og prøver.” En annen presiserer hvordan strategien er nyttig og skriver følgende: "Det kan bli litt langt og usystematisk når man ikke tar tida til å bruke femavsnittsmetoden.”

Mange elever trekker også spesifikt fram at det å få strukturhjelp på avsnittsnivå har vært nyttig. En elev skriver: "Det å utdype meg mer har jeg alltid hatt litt problemer med. Jeg klarer å nevne argumenter for og mot, men har problemer med å forklare dem. Med femavsnittsmetoden har det blitt mye lettere.” Denne eleven peker også på at rammen har hatt betydning for hvordan han/hun utvikler et resonnement.

Elevene skriver videre at det de har lært om skriving kan brukes i flere fag, og de ser derfor at kunnskapen om tekstoppbygging kan overføres mellom fagene. I et av elevsvarene kan vi lese at: "Femavsnittsmetoden er lik i alle fag, så det er ikke vanskeligere å følge metoden i et fag enn i et annet.” En annen elev skriver: "Det er bra at dere legger opp til at vi kan bygge opp teksten på noenlunde lik måte, slik at vi ikke må forandre på måten vi skriver på i hvert fag."

Mange av fritekstsvarene viser at elevene har vært fornøyde med skolens satsing på skriveopplæring. En av elevene sier det slik:

Et bra prosjekt som har gjort meg til en bedre skriver. Det har blitt bedre flyt i tekstene (bindeord) og strukturen er også forbedret. Jeg syntes at dette prosjektet burde fokuseres på i de neste årene også, siden det i ungdomsskolen ikke var så mye fokus på fagskriving.

Eleven mener at han/hun har blitt en bedre skriver, og begrunner det med både bedre flyt og bedre struktur.

Et mindretall av svarene viser at enkelte elever har hatt motforestillinger til skolens satsing og til bruken av femavsnittsmetoden som skriveramme. Fritekstsvarene i denne gruppa var mer entydige, men kan sorteres i to ulike kategorier: skriverammen blir en ekstra utfordring i skrivingen; det er for mye fagskriving.

Det som oftest trekkes fram i disse fritekstsvarene er at rammen oppleves som en utfordring snarere enn en hjelp i skrivearbeidet. En elev skriver for eksempel at det er utfordrende å "få til strukturen og femavsnittsmetoden helt riktig, ettersom mye av karakteren er basert på dette og ikke bare språket og innholdet”. Eleven uttrykker her at metoden er noe man må lære i tillegg til skrivingen. Det er dermed mer enn bare skriving som må til for å lykkes. En annen elev uttrykker også at det er vanskelig å skrive når han/hun må "holde seg til malen, og skrive korrekt, og ikke skrive som jeg egentlig vil skrive”. 
I disse fritekstsvarene trekker også elevene fram at det har vært for mye fokus på fagskriving. Mange uttrykker ønske om en større frihet. En elev skriver for eksempel: "Synes at vi har for mye fagskriving, savner å skrive egne historier istedenfor at alt skal gå etter fakta." En annen skriver: "Kan ha vært litt for intenst med å hamre inn fagskriving, alle lærer på og kan vise kunnskaper på forskjellige måter.” Begge elevene viser her til et ønske om å skrive på en annen måte enn det blir gitt anledning til gjennom dette arbeidet.

\section{Lærernes erfaringer}

På spørsmålet om hva som har vært fokus i skriveopplæringen, sier 13 av 15 lærere at de har brukt femavsnittsmetoden i skriveopplæringen. Det er i hovedsak femavsnittsmetoden som strukturhjelp eller skriveramme som er brukt. Lærerne rapporterer i liten grad om bruk av metoden som prosedyrehjelp i skriveprosessen.

Ingen av lærerne nevner eksplisitt arbeid med for eksempel argumentasjon, bruk av tekstbindere og fagspråk som også var et sentralt poeng i satsingen. Det ser dermed ut som om arbeidet er noe redusert med tanke på prosjektgruppas intensjon som var at satsingen skulle være med på å utvikle en større skrivekompetanse blant lærere og elever enn bare innføring og opplæring av skriveramme.

På spørsmålet om elevenes skriveutvikling svarer 13 av 15 at bruk av femavsnittsmetoden som skriveramme har bidratt til bedre skriveopplæring og dermed økt elevenes skrivekompetanse. Flere av lærerne utdyper dette, og skriver at elevene generelt sett skriver tekster med bedre struktur, og at de har blitt bedre til å organisere tanker og fagstoff både på tekstnivå og på avsnittsnivå. I lærersvarene kan vi for eksempel lese at elevene nå "bygger opp avsnittene på en god måte slik at det stort sett både er godt innhold og god struktur!" Noen av lærerne er mer spesifikke og viser til at elevene "forholder seg til regelen om ett argument/én ide i hvert avsnitt" og at de "fleste elevene bruker også temasetninger og konkluderende setninger i avsnittene”.

På spørsmålet om lærersamarbeidet svarer alle de 15 lærerne positivt. Det poengteres at samarbeidet gir resultater på to områder. Først og fremst mener lærerne at elevene opplever en mer enhetlig tilnærming til skriving og tekstarbeid. En av lærerne uttrykker at elevene har "stort utbytte av at lærerne bruker noen av de samme begrepene i arbeidet med tekst og i vurdering av tekst» og at et felles begrepsapparat i tilbakemeldinger "gjør elevene mer bevisste på tekstkvalitet”. I tillegg trekker lærerne fram egen kompetanseheving. De skriver for eksempel at en slik felles strategi "har gjort meg mer bevisst på skriveopplæringen i eget fag”. En lærer trekker også fram at han/hun har nytte av å vite hva andre lærere gjør for slik å tilpasse egen undervisning. Han/hun skriver: "Det er bra å vite hva de arbeider med i andre fag slik at jeg kan spille videre på det i eget fag." 


\section{Diskusjon}

Det overordnede spørsmålet vi stilte var hvordan lærerne og elevene opplevde innføringen av skriverammer og et samarbeid på tvers av fag. Datamaterialet vårt er begrenset og gir ingen entydige svar på spørsmålet, men vi mener studien kan belyse noen interessante spørsmål i planleggingen av skriveopplæring i skolen.

\section{Erfaringer med bruk av skriveramme}

Ifølge spørreundersøkelsen mener elevene selv at de har blitt bedre både til å strukturere tekster, til å bygge opp argumentasjon og til å bruke fagspråk. Lærerne som var med i satsingen bekrefter at elevene skriver tekster med bedre struktur enn tidligere både på tekstnivå og på avsnittsnivå, og de mener dette skyldes bruken av femavsnittsmetoden. Lærerne mener også at elevene har blitt bedre til å utdype poengene sine eller fullføre resonnementene, noe som i utgangspunktet var en svakhet ved elevenes tekster. Forskning viser at elever generelt strever med oppbygging av tekster som er strukturert etter andre prinsipp enn kronologi (Freedman \& Pringle, 1984; Berge mfl., 2005; Øgreid, 2016). Siden både elevsvarene og lærersvarene poengterer en bedre tekststruktur, er det nærliggende å anta at skriverammen har bidratt til å gjøre elevene mer bevisste på denne siden ved fagtekster. Lewis og Wray (2002) finner det samme i sine studier. De mener skriverammene ga elevene en støtte de trengte for å utvikle tankene.

Struktur har stor betydning for kvaliteten på fagtekster på dette nivået, men det er selvsagt ikke ensbetydende med gode fagtekster. Noe av kritikken mot bruk av slike faste skrivemønstre i skriveopplæringen har nettopp vært at fokuset på form blir overdrevet, og at opplæringen oppleves som formalistisk.

I fritekstfeltene i undersøkelsen uttrykker flere elever en negativ erfaring med bruken av skriveramme. De hevder at det er vanskelig å lære "en ny måte å skrive på”. De opplever at rammen er et mål i seg selv og at de må bruke rammen eller bygge opp teksten sin i tråd med rammen for å få den anerkjent. Fokuset på form tvinger fram "en annen måte å skrive på enn før” sier en av elevene. En slik opplevelse av skriverammen må sies å være mer til hinder for skrivingen enn til hjelp, og dette viser at noe av kritikken mot en slik skriveopplæring er berettiget. Opplæringen kan bli formalistisk og elevene ser ikke overføringsverdien mellom den eksplisitte opplæringen og tekstskrivingen som blant annet Freedman og Pringle (1984) peker på.

At rammen ble en ekstra utfordring for de svakeste elevene, kommer også fram i svarene fra noen av lærerne. De hevder at svake elever hadde vanskeligheter med å forstå hvordan rammen skulle brukes, og at de i liten grad greide å bruke den som det redskapet den var ment som. I stedet for en strukturhjelp som kunne frigjort ressurser til andre deler av skriveprosessen, så de at denne elevgruppen brukte mye ressurser på å forstå selve rammen. Denne erfaringen 
står i kontrast til resultatene i Ligaards studie der hun framhever at samtlige elever hadde utbytte av skriverammene, men på ulike måter (Ligaard, 2014).

Lærerne nevner også eksempler på at sterke elever har opplevd rammen som stram. En lærer skriver at flere av elevene i denne elevgruppen ble mer opptatt av å holde seg til rammen enn å presentere fagstoff, og mener at elevene unnlot viktige refleksjoner fordi de ikke fikk det til å stemme med strukturen. De mente også at elevene hadde en forståelse av at lærerne ikke anerkjente tekster som avvek fra den strukturen som ble presentert. På den andre siden opplevde en lærer at sterke elever som tidligere hadde vist høy faglig kompetanse, ofte hadde hatt problemer med å avgrense fagstoffet og presenterte for mye fagstoff ubearbeidet. Ved hjelp av skriveramme klarte disse elevene nå å strukturere stoffet og gjøre seg ferdig med ett moment om gangen. Ligaards studie (2014) bekrefter det siste poenget. I hennes studie fikk de sterke elevene gjennom skriverammen et redskap som gjorde at de greide å holde en tematisk sammenheng i tekstene.

For å unngå en opplevelse av at rammene begrenser, er det nødvendig at rammene settes inn i en sammenheng. Elevene må forstå hva rammen er og hvordan den kan brukes i en fase av opplæringen. Dette blir også trukket fram i flere studier (Lewis \& Wray, 2002; Myhill et al., 2012) der det understrekes at rammene må inngå i en lærerstyrt prosess, og ikke brukes som utfyllingsskjema. Rammen må integreres i tekstarbeid og være en støtte i arbeidet, ikke en form for fasit. Etter vår mening må derfor en slik opplæring med et tydelig fokus på form og struktur følges av samtaler rundt flere kjennetegn på god tekstkvalitet.

De fleste kommentarene om femavsnittsmetoden dreier seg om metoden som strukturhjelp. Svært få av elevene har kommentert bruken av metoden som prosedyrehjelp. Siden lærerne heller ikke nevner det, kan det tyde på at det ikke ble vektlagt i arbeidet ut over den opplæringen elevene fikk i den felles oppstartsøkten.

Selv om mange elever har opplevd at arbeidet har gjort dem til bedre skrivere, er ikke alle elevene enige. Det mange savner er å kunne skrive tekster slik de "selv vil”. Flere elever har uttrykt ønske om å skrive flere skjønnlitterære tekster istedenfor fagtekster. Slike synspunkter er legitime innvendinger mot et sterkt fokus på fagskriving, og det er viktig at vi i skolen ivaretar flere måter å bruke skriving på. Parallelt med fagskriving må vi ha rom for å bruke skriving på ulike måter i ulike fag.

\section{Lærersamarbeid om skriveopplæringen}

Tradisjonelt har ansvaret for skriveopplæringen vært lagt til norskfaget, og det er dermed norskfagets sjangre og skrivemåter som har vært utgangspunktet. Når elevene møter andre tekstnormer $\mathrm{i}$ andre fag, er det ikke uvanlig at de opplever det som motstridene og forvirrende. I flere studier blir det pekt på at skriveopplæringen må skje i fagene og på fagenes premisser slik at elevene får kjennskap til de fagspesifikke uttrykksmåtene (Shanahan \& Shanahan, 2014, 2008; 
Maagerø \& Skjelbred, 2010; Fang, 2012). Det er ikke bare innholdet i fagene som er forskjellig, men også språket og de grunnleggende perspektivene (Blikstad-Balas, 2016, s. 26). Det å beherske faget handler derfor om å beherske fagspråket. Et viktig aspekt i denne sammenhengen er hva slags kunnskap den enkelte faglærer har om skriveopplæring og hvor mye skriveopplæring som skal foregå i fagene.

I denne satsingen har samarbeidet mellom lærerne vært avgjørende. En av målsetningene var å skape en felles didaktisk plattform for skriveopplæringen, og dette ble sikret gjennom et tett samarbeid på tvers av fag gjennom hele skoleåret. Lærersamarbeidet har ført til at lærerne har tatt i bruk noen felles begreper om skriving og tekstkvalitet som viser seg å ha vært nyttig i undervisningen og som blir poengtert også av elevene.

Flere lærere skriver i undersøkelsen at de før oppstarten manglet verktøy og begreper for å gripe tak i de språklige aspektene ved elevtekster. Mange mente også at de bevisst hadde unngått å kommentere språklige aspekter ved elevarbeidene fordi de mente det ikke hadde betydning for fagkunnskapen. De fleste opplevde en tydelig nytteverdi av samarbeidet med de andre lærerne. Noen hevdet også at de gjennom arbeidet med skriving har blitt mer bevisste på hvordan elevene formidler fagkunnskap i tekster. "Det har blitt lettere å se forskjeller mellom faglig forståelse og oppgulp fra kilder» skriver en av lærerne. Flere lærere som ikke er språklærere, nevner blant annet at de fikk et mer nyansert språk for å gi tilbakemelding på tekst. De kunne være mer spesifikke spesielt med tanke på oppbyggingen på avsnittsnivå og bruken av tekstbindere.

Samarbeidet mellom lærerne førte til at de måtte tydeliggjøre normene for tekstkvalitet som gjelder for sine fag. Dette har vært med på å synliggjøre både likheter og forskjeller, og dermed har det elevene opplever som ulikheter mellom fagenes tekstnormer blitt mindre. Denne betydningen er i tråd med et av Kringstad og Kvithylds (2013) prinsipper for god skriveopplæring, og det bekreftes i et liknende arbeid gjort ved Nadderud videregående skole (Flyum og Hertzberg, 2011, s. 10). Satsingen ved skolen har ført til at lærerne i større grad enn før har kommunisert kravene til fagtekster til elevene og tydeliggjort forventninger de har til elevenes tekster.

Flere av elevene skrev i fritekstfeltet at de i liten grad hadde bruk for femavsnittsmetoden i fag som naturfag og geografi. De hevder at de i disse fagene skriver lite, stort sett er det de skriver svar på konkrete spørsmål. Om de skriver lengre tekster, er det rapporter der de likevel ikke har bruk for den tekststrukturen og prosedyrehjelpen femavsnittsmetoden tilbyr. Dette bekreftes i noen grad av både naturfaglærere og geografilærere. Geografi er et totimersfag der det er lite tid til skriving i timene, fagstoffet blir formidlet muntlig og vurdert gjennom korte prøver uten krav til sammenhengende tekst, ifølge en av lærerne. Noen av naturfaglærerne har uttrykt motforestillinger til fokuset på skriving fordi det tar for mye tid fra det å jobbe med fag. En slik innvending er selvsagt knyttet til hvordan man definerer fagkunnskap og hvordan man velger å vurdere 
elevenes fagkunnskaper. Om man ser på skrivingen som et redskap for læring vil betydningen oppleves annerledes.

Maagerø og Skjelbred (2010) mener at skriving er viktig også i naturfagene, og de poengterer at skriveopplæring i de naturfaglige sjangrene må ha en plass i naturfagundervisningen. Et vesentlig poeng her er at skriveopplæringen i naturfag må foregå slik at den er i tråd med fagets egenart. Når flere av naturfag- og geografilærerne ved skolen ikke opplever at fellesarbeidet med skriving har vært nyttig, kan det skyldes at fagets egenart ikke har blitt tilstrekkelig ivaretatt.

\section{Dialog om tekst}

Intervensjonen vi har studert har hatt en eksplisitt opplæring og bruk av en fast skriveramme som fokus. Det har altså vært et tydelig fokus på tekstens form siden det var det lærerne i utgangspunktet mente var den største svakheten ved elevtekstene. Det som etter hvert har vist seg å ha hatt størst betydning, ifølge lærerne, er ikke skriverammen i seg selv, men oppmerksomhet rundt skrivingen og skriveopplæringens plass i fagene. Flere lærere poengterer at læringsfellesskapet har bidratt til at de samtaler med elevene om tekster på en annen måte både underveis i skrivingen og i evalueringen av elevtekster. Ifølge Jon Smidt (2011, s. 29) er denne samtalen et viktig fundament i skriveopplæringen. Gjennom samtalene utvikler elevene et fagspråk om tekst eller et metaspråk som gjør at de i større grad kan vurdere egen skriving og skriveutvikling.

“Å skrive er å være i dialog med andre [...]”, hevder Fjørtoft (2014, s. 164), og det er gjennom en slik dialog elevene kan utvikle forståelse for tekstkvalitet og egen skrivekompetanse, fortsetter han. Han tar her opp det samme poenget, et poeng som vi mener er et av de viktigste resultatene av satsingen på skolen, nemlig samtalene om tekst og tekstkvalitet i alle fasene av skriveprosessen. Bruken av femavsnittsmetoden har gitt både elever og lærere et felles metaspråk for å kunne snakke om både tekstoppbygging og tekstkvalitet.

Lærerne mener også at arbeidet har ført til at de gir elevene bedre tilbakemeldinger på tekst. Tidligere var rollene mer uavklarte, og flere samfunnsfaglærere og naturfaglærere var usikre på i hvilken grad de skulle kommentere det språklige.

\section{Avsluttende tanker}

Målet med arbeidet som ble gjennomført ved skolen var både å skape et felles fundament for skriveopplæringen ved skolen og å forbedre elevenes skrivekompetanse gjennom eksplisitt opplæring og bruk av femavsnittsmetoden i alle fag. Det er vanskelig, for ikke å si umulig, å måle en direkte effekt av en slik intervensjon og det har heller ikke vært vår målsetning. Vi har primært vært opptatt av hvilke tanker elever og lærere har gjort seg om skriveopplæring i forbindelse med satsingen. Ifølge spørreundersøkelsene bekrefter både lærere og elever en positiv opplevelse av satsingen. Et viktig spørsmål er om det er bruken av femavsnittsmetoden i seg selv som har hatt betydning. På bakgrunn av lærernes svar 
og elevenes fritekstsvar, kan det se ut som om sammenhengen kan ligge i måten metoden ble brukt på. Satsingen førte til at skriveopplæring ble tatt opp i flere fag, og gjennom lærersamarbeidet og samtaler om tekstene opplevde elevene at opplæringen hadde overføringsverdi på tvers av fagene. Satsingen slik vi ser det, har dermed hatt en vesentlig betydning for hvordan arbeidet med skriving skjer i klasserommet.

\section{Referanser}

Berge, K. L. (2005). Skriving som grunnleggende ferdighet og som nasjonal prøve - ideologi og strategier. I A. J. Aasen \& S. Nome (red.), Det nye norskfaget (s.161-187). Bergen: Fagbokforlaget / Landslaget for norskundervisning.

Berge, K. L., Evensen, L. S., Hertzberg, F. \& Wagle, W. (2005). Ungdommers skrivekompetanse: Bind II, Norskeksamen som tekst. Oslo: Universitetsforlaget.

Blikstad-Balas, M. (2016). Literacy i skolen. Oslo: Universitetsforlaget.

Fang, Z. (2012). Language Correlates of Disciplinary Literacy. Top Lang Disorders, 32(1), 19-34. doi: https://doi.org/10.1097/TLD.0b013e31824501de

Fjørtoft, H. (2014). Norskdidaktikk. Bergen: Fagbokforlaget.

Flyum, K. H. \& Hertzberg, F. (red.) (2011). Skriv i alle fag! Argumentasjon og kildebruk $i$ videregående skole. Oslo: Universitetsforlaget.

Freedman, A. \& Pringle, I. (1984). Why Students Can't Write Arguments. English in Education, 18(2), 73-84.

Graham, S. \& Perin, D. (2007). Writing Next: Effective strategies to improve writing of adolescents in middle and high school - A report to Carnegie Corporation of New York. Washington, D.C.: Alliance for Excellent Education.

Haraldsen, G. (1999). Spørreskjemametodikk etter kokebokmetoden. Oslo: Ad Notam Gyldendal.

Helstad, K. \& Hertzberg, F. (2013). Faste mønstre som læringsstøtte i skriveundervisningen. Erfaringer fra et tverrfaglig utviklingsarbeid blant lærere i videregående skole. I D. Skjelbred \& A. Veum (red.), Literacy i læeringskontekster (s.225-248). Oslo: Cappelen Damm Akademisk.

Hertzberg, F. (2012). Grunnleggende ferdigheter - hva vet vi om skolenes praksis? I G. Melby \& S. Matre (red.), Å skrive seg inn i læereryrket (s.33-48). Trondheim: Akademika forlag.

Hertzberg, F. (2009). Skolen og grunnleggende ferdigheter. I J. Møller, T. S. Prøitz \& P. Aasen (red.), Kunnskapsløftet - tung bør å bære. Underveisanalyse av styringsreformen $i$ skjæringspunktet mellom politikk, administrasjon og profesjon (s.137-146). Universitetet i Oslo: ILS og NIFU Step.

Håland, A. (2013). Bruk av modelltekstar i sakprega skriving på mellomtrinnet: Ei undersøking av korleis modelltekstar set spor i elevtekstar og korleis elevar posisjonerar seg i ulike sakprega skrivesituasjonar. Doktoravhandling, Universitetet i Stavanger. Hentet fra https://brage.bibsys.no/xmlui/bitstream/id/183974/Anne_Haaland.pdf

Igland, M.-A. (2007). "Svinaktig vanskelig”? Skriftleg argumentasjon på ungdomssteget. I S. Martre \& T. L. Hoel (red.), Skrive for nåtid og framtid (bind I, s. 277-291). Trondheim: Tapir forlag.

Kringstad, T. \& Kvithyld, T. (2013). Fem prinsipper for god skriveopplæring, Bedre Skole, 2, 71-79. 
Lewis, M. \& Wray, D. (2002). Writing Frames. Scaffolding children's non-fiction writing in a range of genres. National Centre for Language and Literacy, University of Reading.

Ligaard, M. (2014). Ord blir til setninger, setninger til avsnitt. Systematisk skriveundervisning med femavsnittsmetoden, Norsklcereren, 4, 20-26.

Ligaard, M. (2012). Femavsnittsmetoden som skrivepedagogisk verktøy i videregående skole: Et praktisk perspektiv på skriveundervisning og fagskriving i engelsk og naturfag. Masteropgave, Universitetet i Oslo. Hentet fra: https://www.duo.uio.no/bitstream/handle/10852/34116/LigaardMaster.pdf?sequence $=1$ \&isAllowed $=\mathrm{y}$

Myhill, D. A., Jones, S. M., Lines, H. \& Watson, A. (2012). Re-thinking grammar: the impact of embedded grammar teaching on students' writing and students' metalinguistic understanding, Research Papers in Education, 27(2), 139-166. doi: https://doi.org/10.1080/02671522.2011.637640

Maagerø, E. \& Skjelbred, D. (2010). De mangfoldige realfagtekstene: Om lesing og skriving i matematikk og naturfag. Bergen: Fagbokforlaget.

Postholm, M. B. \& Jacobsen, D. I. (2011). Lereren med forskerblikk. Kristiansand: Høyskoleforlaget.

Ringdal, K. (2014). Enhet og mangfold. Samfunnsvitenskaplig forskning og kvantitativ metode. Bergen: Fagbokforlaget.

Shanahan, T. \& Shanahan, C. (2014). Does Disciplinary Literacy Have a Place in Elementary School? The Reading Teacher, 67(8), 636-639.

Shanahan, T. \& Shanahan, C. (2008). Teaching Diciplinary Literacy to Adolescents: Rethinking Content-Area Literacy, Harvard Educational Review, 78(1), 40-59.

Smidt, J. (2011). Ti teser om skriving i alle fag. I J. Smidt, R. Solheim \& A. J. Aasen (red.), På sporet av god skriveopplæring (s. 9-41). Trondheim: Tapir akademisk forlag.

Øgreid, A. K. (2016). Skriveramme som støtte i arbeidet med fagskriving? Studie av 8. klasse elevers tekstskaping i samfunnsfag, Acta Didactica Norge, 10(1), art. 3.

Øgreid, A. K. (2008). Stjålen skrivefrihet? Om argumenterende skriving på ungdomstrinnet. I M. E. Nergård \& I. Tonne (red.), Språkdidaktikk for norsklæerere - mangfold i språk og tekster (s. 67-82). Oslo: Universitetsforlaget. 